\title{
Soil Bacterial and Fungal Composition and Diversity Responses to Seasonal Deer Grazing in a Subalpine Meadow
}

\author{
Andéole Niyongabo Turatsinze, Baotian Kang, Tianqi Zhu, Fujiang Hou and Saman Bowatte *(D)
}

check for updates

Citation: Turatsinze, A.N.; Kang, B.; Zhu, T.; Hou, F.; Bowatte, S. Soil Bacterial and Fungal Composition and Diversity Responses to Seasonal Deer Grazing in a Subalpine Meadow. Diversity 2021, 13, 84. https:// doi.org/10.3390/d13020084

Academic Editor: Michael Wink

Received: 10 January 2021

Accepted: 13 February 2021

Published: 18 February 2021

Publisher's Note: MDPI stays neutral with regard to jurisdictional claims in published maps and institutional affiliations.

Copyright: (c) 2021 by the authors. Licensee MDPI, Basel, Switzerland. This article is an open access article distributed under the terms and conditions of the Creative Commons Attribution (CC BY) license (https:// creativecommons.org/licenses/by/ $4.0 /)$.
State Key Laboratory of Grassland Agro-Ecosystems, Key Laboratory of Grassland Livestock Industry Innovation, Ministry of Agriculture and Rural Affairs, College of Pastoral Agriculture Science and Technology, Lanzhou University, Lanzhou 730020, China; andeole2017@lzu.edu.cn (A.N.T.); kangbt18@lzu.edu.cn (B.K.); zhutq18@lzu.edu.cn (T.Z.) ; cyhoufj@lzu.edu.cn (F.H.)

* Correspondence: samanbowatte@lzu.edu.cn

Abstract: Soil microbial composition and diversity are widely recognized for their role in ecological functioning. This study examined the differences of soil microbial communities between two seasonally grazed grasslands. The study area was in the Gansu red deer farm located on the Qilian Mountain range in the Gansu province of northwestern China. This farm adopted a seasonal rotation grazing system whereby grasslands at higher altitudes are grazed in summer (SG), whilst grasslands at lower altitudes are grazed in winter (WG). The soil bacterial and fungal communities were examined by Illumina MiSeq sequencing. We found that soil water content (SWC), organic carbon $(\mathrm{OC})$, total carbon $(\mathrm{TC})$, and total nitrogen $(\mathrm{TN})$ were significantly higher, whereas the $\mathrm{C} / \mathrm{N}$ ratio was significantly lower in SG than WG pastures. The $\alpha$-diversity of bacteria was greater than that of fungi in both pastures, while both bacterial and fungal $\alpha$-diversity were not significantly different between the pastures. The bacterial $\beta$-diversity was significantly different between the pastures, but fungal $\beta$-diversity was not. The bacterial phylum Actinobacteria and fungal phylum Ascomycota were dominant in both pastures. The relative abundance of Actinobacteria in soil was significantly higher in WG pastures, whereas the relative abundance of Proteobacteria in soil was significantly higher in SG pastures. Significant correlations between bacterial and fungal phyla and soil properties were observed, but this varied between the two grasslands. This study showed that distinct microbial community structures developed in two pastures within the same geographic location that were grazed in different seasons.

Keywords: Gansu red deer; seasonal grazing; metabarcoding

\section{Introduction}

Most grasslands in the world are grazed by livestock. It is widely accepted that animal grazing is beneficial to grassland nutrient cycling [1,2] and biodiversity [3,4]. Yet, many recent studies have warned that grassland degradation is induced by grazing animal activities such as defoliation, treading, and excretion [5-7]. Excessive foraging by grazing animals can reduce vegetation cover [8,9], creating bare patches within the pasture and increasing vulnerability to soil erosion. Additionally, livestock trampling on the soil surface can cause soil compaction and pugging, which can increase the bulk density of the soil, affecting soil aeration $[10,11]$. These changes in soil physical properties can promote surface runoff. To overcome these detrimental effects of continuous grazing, some herders employ a grazing system based on seasonal rotation. This practice is common in some alpine grasslands in the Qinghai Tibetan Plateau (QTP) in China, where a seasonal rotation between higher-altitude grasslands is utilized in summer, and lower-altitude grasslands is utilized in winter [12].

Animal grazing behaviors can have a significant impact on soil physical properties, nutrient cycling [13], plant community characteristics [14,15], litter distribution and decomposition [16,17], and the distribution of urine and faeces. These grazing-induced impacts 
can lead to changes in the soil microbial community [18]. For example, several studies have found that grazing intensity has a strong relationship with soil microbial biomass and diversity $[19,20]$. Higher microbial diversity was associated with intermediate grazing intensity [21,22], while light and moderate grazing intensities responded differently to microbial $\alpha$ - and $\beta$-diversities [23]. Qu et al. [24] found that soil bacterial diversity indices varied under different plant species growing under different grazing intensities. Other studies have indicated that bacterial and fungal community diversity can be differently impacted under long-term grazing exclusion, where plant and bacterial succession was seen to evolve more rapidly and in parallel to each other compared to fungal succession [25]. Though there are numerous studies on the impact of grazing on soil microbial communities, information on how seasonal grazing impacts soil microbial communities is lacking despite being vital for policy designs promoting best grazing management strategies that help maintain healthy grassland systems. This paper aims to address this research gap.

The study area was a subalpine meadow located on the Qilian mountain range in the Gansu province of northwestern China. Livestock grazing has been the main land use type in this area for many years [12]. The study area was a part of 5900 ha of grassland managed by a single commercial entity engaged in farming Gansu red deer. This farm adopted the seasonal rotation grazing system where grasslands at high altitudes approximately 2930-2834 $\mathrm{m}$ a.s.l. are grazed in summer, and grasslands around $2802-2745 \mathrm{~m}$ a.s.l. are grazed in winter. In this study, we hypothesized that seasonal grazing differences might impact soil microbial community structure. The aim of this paper is to describe the differences between the effects of summer and winter grazing on soil properties and soil bacterial and fungal community structure in two pastures within the same geographic location.

\section{Materials and Methods}

\subsection{Research Site}

The soil samples for this study were collected from two separate grassland areas grazed by Gansu red deer (Cervus elaphus kansuensis) in summer and winter at the Sunan Deer Farm, situated in an subalpine meadow north of Qilian Mountain Range, Sunan Yugur Nationality Zizhi county, Gansu province, China ( $38^{\circ} 87^{\prime}$ N, $99^{\circ} 65^{\prime}$ E) (Figure 1). The two grasslands will hereafter be referred to in this paper as the summer grazed pasture (SG) and winter grazed pasture (WG).
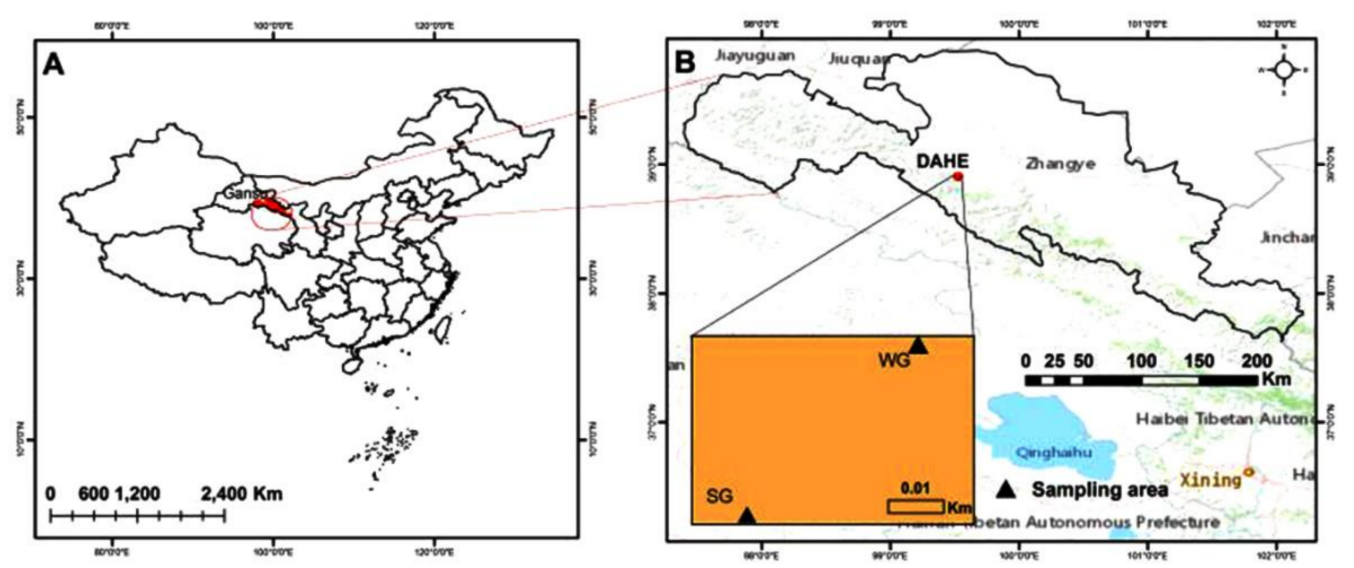

Figure 1. The experimental sitemap illustrating the location of Gansu Province in China (A) and the geographical locations of the summer (SG) and winter (WG) grazing pasture areas at Dahe, Sunan county in Gansu Province (B).

The summer season is May to July, while the winter season is October to April. The average annual rainfall is about $253.7 \mathrm{~mm}$ where the rainy season is mostly spread between the May to October period. The average annual temperature is $3.6^{\circ} \mathrm{C}$ with a low 
temperature of $-18.4^{\circ} \mathrm{C}$ in January and a high temperature of $13.9{ }^{\circ} \mathrm{C}$ in July. The plant growth period is generally from April to September. Plants return to green in late April, optimum growth is in July, and withering is in September. The plant community in the SG pastures was dominated by Caragana jubata (Pallas) Poiret in Lamarck, Potentilla fruticosa Linnaeus, Poa poiphagorum Bor, Stipa purpurea Grisebach, Poa alpigena (Fr.) Lindm., Leymus secalinus (Georgi) Tzvelev, Carex kansuensis (Nelmes) Bull., Potentilla anserina Linnaeus, Thalictrum alpinum Linnaeus, Artemisia annua Linnaeus, Polygonum viviparum Linnaeus, Oxytropis kansuensis Bunge, and Anaphalis bulleyana (J. F. Jeffr.) Chang [26,27], whereas the WG pasture was dominated by Stipa purpurea Grisebach, Leymus secalinus (Georgi) Tzvele, Poa annua Linnaeus, Achnatherum inebrians (Hance) Keng ex Tzvelev, and Carex atrata subsp. aterrima (Hope) S. Yun Liang [27,28].

\subsection{Sample Collection and Processing}

In October 2018, four replicate soil samples were collected from each of the SG and WG pastures (Table 1). Soil samples were collected to a depth of $10 \mathrm{~cm}$ using a $10 \mathrm{~cm}$ diameter soil corer. In each pasture, soil samples were collected from 4 areas $(10 \mathrm{~m} \times 10 \mathrm{~m})$, and within each sampling area, five soil cores approximately $5 \mathrm{~m}$ apart were collected, pooled, and mixed thoroughly, resulting in a total of 8 soil samples ( 2 sites $\times 4$ replicates) for the study.

Table 1. Soil sampling locations and geographic information.

\begin{tabular}{|c|c|c|c|c|}
\hline Sampling Location ID & Latitude (N) & Longitude (E) & Altitude (m) & Location \\
\hline $\mathrm{SG}^{\mathrm{a}}$ & $38^{\circ} 54.401^{\prime}$ & $99^{\circ} 31.586^{\prime}$ & 2834 & Dahe, Sunan, Gansu, China \\
\hline $\mathrm{SG}^{\mathrm{b}}$ & $38^{\circ} 54.332^{\prime}$ & $99^{\circ} 31.526^{\prime}$ & 2866 & Dahe, Sunan, Gansu, China \\
\hline$S^{c}{ }^{c}$ & $38^{\circ} 54.251^{\prime}$ & $99^{\circ} 31.457^{\prime}$ & 2907 & Dahe, Sunan, Gansu, China \\
\hline $\mathrm{SG}^{\mathrm{d}}$ & $38^{\circ} 54.181^{\prime}$ & $99^{\circ} 31.388^{\prime}$ & 2930 & Dahe, Sunan, Gansu, China \\
\hline$W_{G}^{a}$ & $38^{\circ} 55.587^{\prime}$ & $99^{\circ} 32.528^{\prime}$ & 2745 & Dahe, Sunan, Gansu, China \\
\hline$W^{b}$ & $38^{\circ} 55.151^{\prime}$ & $99^{\circ} 32.465^{\prime}$ & 2756 & Dahe, Sunan, Gansu, China \\
\hline$W^{c}{ }^{c}$ & $38^{\circ} 54.582^{\prime}$ & $99^{\circ} 32.410^{\prime}$ & 2773 & Dahe, Sunan, Gansu, China \\
\hline$W^{d}$ & $38^{\circ} 54.468^{\prime}$ & $99^{\circ} 32.262^{\prime}$ & 2802 & Dahe, Sunan, Gansu, China \\
\hline
\end{tabular}

Note: ${ }^{a}, b, c$, and ${ }^{d}$ are sampling points within the SG and WG pastures.

First, visible roots or other debris were removed from the soil samples. Then the samples were passed through a $2 \mathrm{~mm}$ sieve. Each sample was divided into three subsamples. One sub-sample was transported to the laboratory in a portable freezer and stored at $-20{ }^{\circ} \mathrm{C}$ for microbial community analysis. Another subsample was used to analyze the soil water content (SWC). The remaining soil was air-dried beforehand in order to measure soil physicochemical properties, including $\mathrm{pH}$, total nitrogen (TN), total carbon (TC), total sulfur (TS), and organic carbon (OC).

\subsection{Soil Physicochemical Analysis}

Soil water content $(\% w / w)$ was determined by oven drying (DHG-9240, Shanghai Jing Macro, Shanghai, China) at $105^{\circ} \mathrm{C}$ to a constant weight. Soil $\mathrm{pH}$ was determined by a $\mathrm{pH}$ meter (PE-10, Sartorious, Germany) using a slurry with a 1:5 soil-to-water ratio. Total soil $\mathrm{C}, \mathrm{TN}$, and TS were determined using an elemental analyzer (Elementar Vario EL/micro cube, Hanau, Germany). Soil organic carbon (OC) was determined by the Walkley-Black wet digestion method with $\mathrm{H}_{2} \mathrm{SO}_{4}-\mathrm{K}_{2} \mathrm{Cr}_{2} \mathrm{O}_{7}$ [29].

\subsection{Microbial Community Analysis}

Soil DNA was extracted using a FastDNA ${ }^{\circledR}$ spin kit (MP Biomedicals, Santa Ana, CA, USA) according to the manufacturer's instructions. DNA quantity and purity were determined using the Nanodrop ${ }^{\circledR}$ ND-1000 UV-visible spectrophotometer (Nanodrop Technologies, Wilmington, DE, USA) and stored at $-20^{\circ} \mathrm{C}$ until further use. The Illumina MiSeq sequencing was carried out at Shanghai Personal Biotechnology Co., Ltd. (Shanghai, 
China). The MiSeq sequencing library preparation, PCR amplicon purification, Illumina MiSeq sequencing, sequencing data processing, and operational taxonomic unit (OTU) generation were carried out as described in Kang et al. [30]. The relative abundance of phyla and genera in each sample was used to describe the microbial community composition and diversity. The relative abundance of each taxonomic group was calculated by dividing the number of reads for any given group by the total number of reads obtained in that sample. The Chao 1 species richness index and the Shannon-Wiener $\left(\mathrm{H}^{\prime}\right)$ community evenness index were used to estimate the alpha diversity (diversity within a sample) of soil bacterial and fungal communities. The Chao 1 index was calculated as proposed by Chao [31], where the number of OTUs detected only once and twice in the community (i.e., "singleton" and "doubleton") is used to estimate the number of species in the community using Equation (1). The Shannon-Wiener ( $\left.\mathrm{H}^{\prime}\right)$ estimates were calculated using Equation (2), as demonstrated by Shannon [32].

$$
\text { Chao } 1=S_{o b s}+\frac{F_{1}^{2}}{2 F_{2}}
$$

where $S_{o b s}$ is the observed number of species, $F_{1}$ and $F_{2}$ are the count of singletons and doubletons, respectively.

$$
H=-\sum_{i=0}^{\delta}\left(P_{i} \log _{2} P_{i}\right)
$$

where $\delta$ is the number of OTUs and $P_{i}$ is the proportion of the community represented by OTU $i$.

Non-metric multidimensional scaling (NMDS) analysis was carried out using a weighted UniFrac distance matrix [33] using R software [34] to compare the soil microbial community dissimilarity between the samples (beta diversity).

\subsection{Statistical Analysis}

Analysis of variance (ANOVA) was carried out to test the statistical significance of the effects of grassland type on $\alpha$-diversity, the relative abundance of bacterial and fungal phyla and genera, and soil properties. The statistical significance of the means was compared using Duncan's multiple range test. Statistical analysis was carried out using Statistical Product and Service Solutions (SPSS) software version 23.0 (SPSS Inc., Chicago, IL, USA). The normal distribution of the data was assessed by the Shapiro-Wilk test. Microbial community differences between the two grassland sites were statistically tested by analysis of similarities (ANOSIM) with 999 permutations using QIIME software. In all analyses, statistical significance was determined at $p \leq 0.05$. The linkage between microbial communities and soil physicochemical properties was examined using redundancy analysis (RDA) using the Canoco 4.5 software (Microcomputer Power, Ithaca, NY, USA). The relationships between dominant bacterial and fungal phyla and soil physicochemical properties were examined by Pearson correlations using SPSS software $\left(\right.$ IBM $^{\circledR}$ SPSS $^{\circledR}$ Statistics Version 23)

\subsection{Nucleotide Sequence Accession Numbers}

The nucleotide sequences retrieved from this study have been deposited in the NCBI GenBank under submission number SUB8164136 and the BioProject accession number PRJNA663459 (bacteria) and SUB8164136 and BioProject accession number PRJNA664266 (fungi).

\section{Results and Discussion}

This study investigated differences in soil properties and the structure of soil microbial communities between two pastures located within the same geographic location (Figure 1 and Table 1), grazed by Gansu red deer in different seasons. We found that soil physicochemical properties between the SG and WG pastures were different (Table 2). Total carbon, TN, 
OC, and SWC were significantly higher in SG than in WG pasture, while the $\mathrm{C} / \mathrm{N}$ ratio was significantly lower in SG pasture (Table 2). There was no significant difference in TS and soil $\mathrm{pH}$ between the pastures. The observed soil physicochemical differences can be attributed to the differences in vegetation characteristics [35]; animal grazing behaviors [36-39]; and the complex interactions of vegetation, grazing, and seasonal impacts. Ingram et al. [40] found that seasonal shifts in C3 and C4 plant species due to different grazing levels contributed to organic carbon and total nitrogen accumulation and losses, which in turn affected the soil microbial community. The soil physicochemical differences between SG and WG pastures may have led to the establishment of different bacterial and fungal composition between the two pastures.

Table 2. Differences in soil physicochemical properties at summer grazed (SG) and winter grazed (WG) pastures. The values are mean \pm standard error. Bold $p$-values indicate statistically significant differences between means from one-way ANOVA at $p \leq 0.05$.

\begin{tabular}{cccc}
\hline Soil Properties & Summer Grazing & Winter Grazing & $p$-Value \\
\hline Total Nitrogen $\left(\mathrm{g} \mathrm{kg}^{-1}\right)$ & $4.6 \pm 0.29$ & $2.8 \pm 0.13$ & $\mathbf{0 . 0 0 2}$ \\
Total Carbon $\left(\mathrm{g} \mathrm{kg}^{-1}\right)$ & $45.3 \pm 2.78$ & $31.3 \pm 0.46$ & $\mathbf{0 . 0 0 3}$ \\
Total Sulfur $\left(\mathrm{g} \mathrm{kg}^{-1}\right)$ & $0.4 \pm 0.14$ & $0.5 \pm 0.02$ & 0.401 \\
$\mathrm{pH}$ & $7.47 \pm 0.120$ & $7.59 \pm 0.055$ & 0.372 \\
Organic Carbon $\left(\mathrm{g} \mathrm{kg}^{-1}\right)$ & $41.4 \pm 3.18$ & $26.9 \pm 1.89$ & $\mathbf{0 . 0 0 8}$ \\
C/N & $9.95 \pm 0.040$ & $11.14 \pm 0.356$ & $\mathbf{0 . 0 1 6}$ \\
Water Content (\%) & $13.74 \pm 2.43$ & $7.16 \pm 0.748$ & $\mathbf{0 . 0 4 2}$ \\
\hline
\end{tabular}

Twenty-six bacterial phyla were identified in this study. The most dominant five phyla in both pastures (94.8\% of the total sequences) were Actinobacteria, Proteobacteria, Acidobacteria, Chloroflexi, and Gemmatimonadetes (Figure 2A). These phyla were found to be dominant in several other alpine grasslands [41-43]. The Actinobacteria abundance was significantly higher in WG pastures, while the abundance of Proteobacteria was significantly higher in SG pastures (Figure 2A). The differences in the abundance of these phyla reflect the soil fertility status of the two pastures. Proteobacteria exhibit a copiotrophic life strategy, generally thriving with high resource availability-a feature observed in SG pasture compared to the WG pasture. Actinobacteria were often dominantly observed in arid environments and are generally characterized by an oligotrophic life strategy, growing under low resource availability $[44,45]$. This was evident in our study; soil fertility was lower in WG pastures compared to SG, and the Actinobacteria abundance was greater in WG pastures. The relative abundances of Bacteroidetes and Rokubacteria were also significantly different between the two pastures (Figure 2A). In our study, Verrucomicrobia phyla showed a strong significant positive correlation with TC and TN in SG pastures (Table 3), which might support the fact that their abundances were higher in SG compared to WG pastures.

There were 381 bacterial genera identified in this study. The distribution of the most dominant 20 genera, which represented $98.7 \%$ of total sequences, is shown in Figure $2 \mathrm{~B}$. Among the most dominant 20 genera, the relative abundance of nine genera was significantly different between the pastures (Figure 2B). Here, bacterial genera Conexibacter, Gemmatirosa, and Blastococcus significantly differed between the two pastures at $p \leq 0.01$, while Kribbella, Rhodoplanes, Bradyrhizhobium, Rubrobacter, Nucardioides, and Actinoplanes significantly differed at $p \leq 0.05$ (Figure 2B). The RB41 genus was the most abundant among the top 20 dominant bacterial genera in both pastures, and its abundance was not significantly different between pastures (Figure 2B). Ma et al. [46] found that RB41 was dominant in several alpine grasslands on the Tibetan Plateau, and its abundance did not vary significantly with soil physicochemical properties. 
(A)

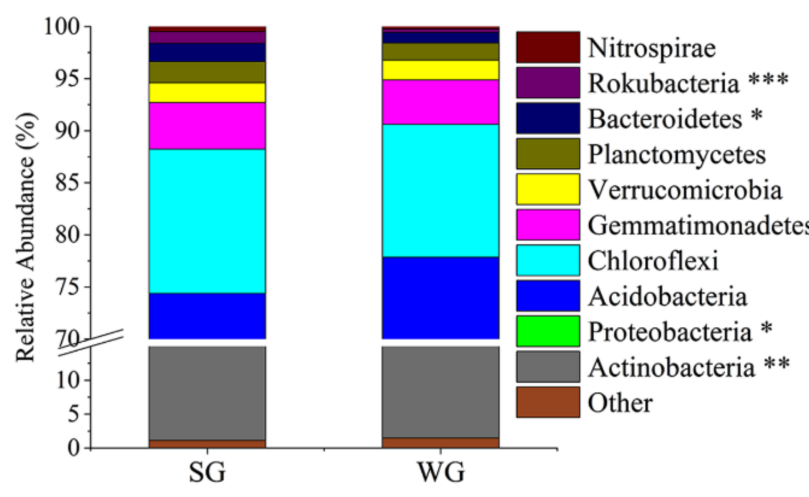

(C)

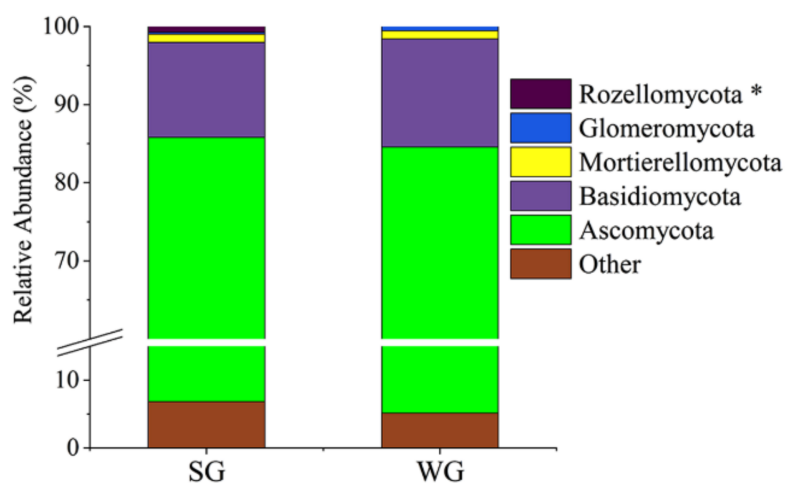

(B)

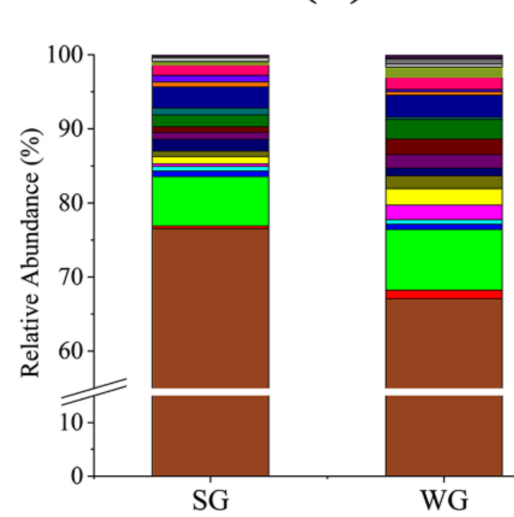

(D)

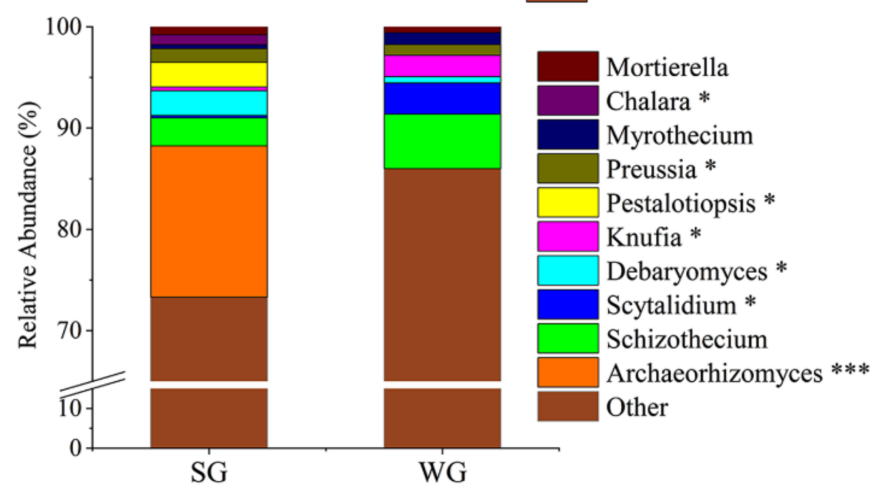

Figure 2. Relative abundances of dominant bacterial phyla (A), bacterial genera (B), fungal phyla (C), and fungal genera (D) between two different grazing scenarios-summer (SG) and winter (WG). Legends marked *, **, and *** are significantly different groups at $p \leq 0.05, p \leq 0.01$, and $p \leq 0.001$, respectively.

Eight fungal phyla were identified in this study. The five most dominant phyla in both pastures were Ascomycota, Basidiomycota, Mortierellomycota, Glomeromycota, and Rozellomycota (Figure 2C). These five phyla represented more than $90 \%$ of the fungal sequences in all the samples from both pastures. Fungal phyla Ascomycota and Basidiomycota represented $80 \%$ of sequences, but the relative abundance of these phyla was not significantly different between the two pastures. These fungal phyla are globally dominant [47], where Ascomycota show a greater rate of evolution than Basidiomycota [48], potentially explaining their higher abundance in both SG and WG pastures. There were 251 fungal genera identified in this study. There were significant differences between the relative abundance of 7 out of the top 10 abundant fungal genera. The fungal genus Archaeorhizomyces was significantly higher in SG pastures and significantly differed between the two pastures $(p \leq 0.001)$. At the same time, Chlara, Preussia, Pestalotiopsis, Knufia, Debaryomyces, and Scytalidium significantly differed at $p \leq 0.05$ (Figure 2D).

There was no significant difference between species richness, indicated by Chao 1 , or evenness, indicated by the Shannon index, between the pastures for both bacteria and fungi, indicating that the $\alpha$-diversity was similar in the two pastures (Figure 3 ).

Nevertheless, $\alpha$-diversity was higher for bacteria than fungi in both pastures, indicating that these soils are more bacteria-dominant. Greater fungi:bacteria ratios are generally linked to higher carbon storage in soil [49], meaning that both soils in our study may possess lower carbon storage capacity. The $\beta$-diversity examined by the NMDS analysis (Figure 4) indicated distinct soil bacterial communities in each of the SG and WG pastures (ANOSIM R $=0.8, p$-value $=0.02$ ), but fungal communities were not significantly different 
(ANOSIM R $=0.0, p$-value $=0.488)$. Zhong et al. [50] reported that the variation in plant species affects soil bacterial and fungal community diversity. The difference in bacterial $\beta$-diversity in our study may be linked to the difference in plant species composition between SG and WG pastures. By examining a range of grasslands around the world, Prober et al. [51] demonstrated that differences in plant diversity mostly predict bacterial $\beta$-diversity rather than fungal $\beta$-diversity. This is consistent with our findings, where we only observed significant differences between bacterial $\beta$-diversity (Figure 4 ).

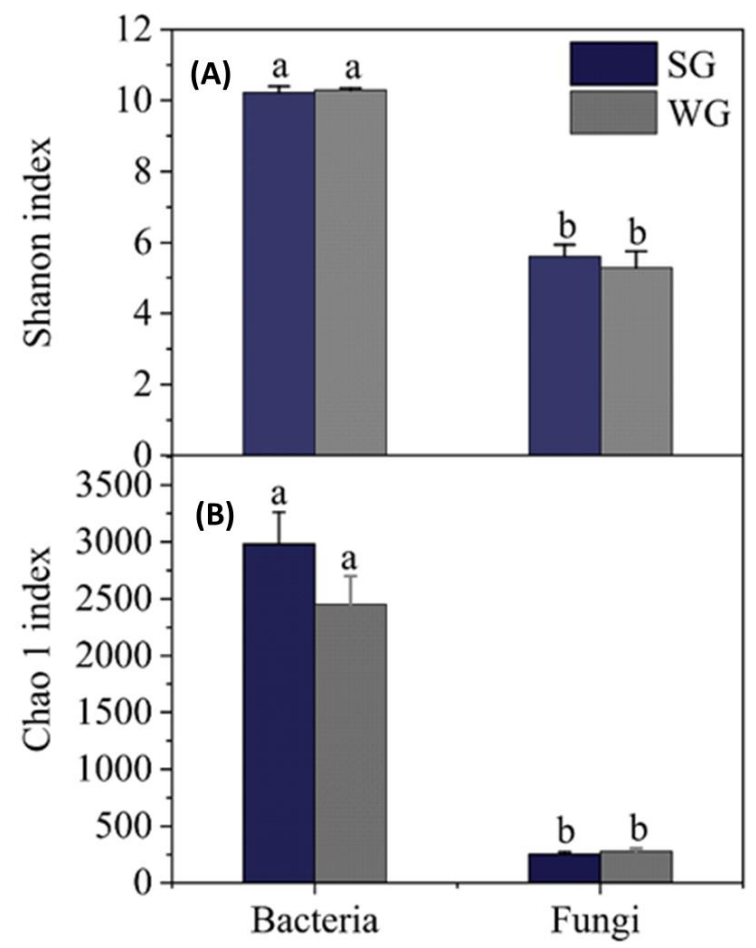

Figure 3. Microbial $\alpha$-diversity differences in summer (SG) and winter (WG) grazing pastures. (A) Microbial evenness indicated by Shannon-Wiener index. (B) Microbial species richness indicated by Chao 1. Different lowercase letters indicate a statistical significance at $p \leq 0.5$ within a microbial group.

(A)

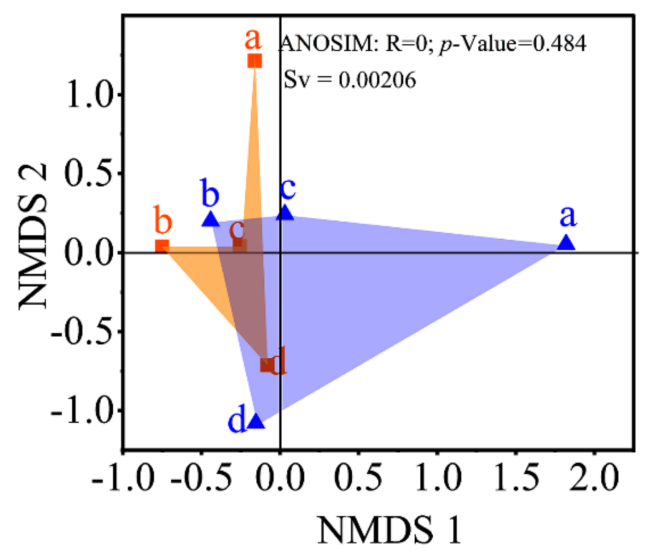

(B)

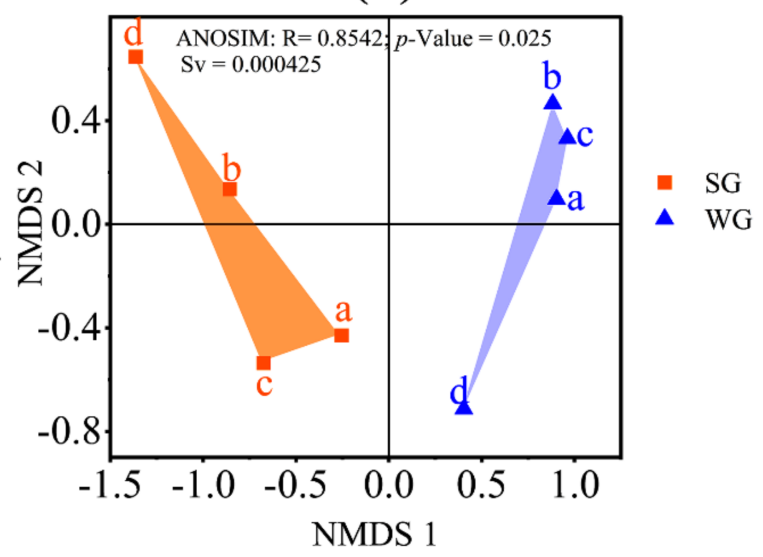

Figure 4. Non-metric multidimensional scaling (NMDS) plots to illustrate fungal (A) and bacterial (B) beta diversities as impacted by seasonal summer (SG) and winter (WG) grazing. Letters a, b, c, and d indicate replicates. Sv are stress values indicating the goodness of fit. 
The importance of soil nutrients in shaping soil microbial abundance has been demonstrated in several previous studies [42,52,53]. Strong and significant correlations between soil nutrients and microbial abundances were observed in our study as well. RDA ordination biplots evaluated the linkage between fungi (Figure 5A,B) and bacteria (Figure 5C,D) and soil properties. Soil organic carbon, TN, TC, and SWC were strongly associated with the SG pasture bacterial community, whereas soil $\mathrm{pH}$ and $\mathrm{C} / \mathrm{N}$ ratio were strongly associated with the WG pasture community. Soil $\mathrm{pH}$ has been widely reported as the dominant factor in determining soil microbial structure [54-56]; this was evident in our study, where fungal phyla, Glomeromycota, and about 12 dominant bacterial genera showed a strong positive relationship with soil $\mathrm{pH}$ (Figure 5A,D, Tables 3 and 4). Most bacterial phyla showed a strong link to the SG pasture bacterial community, while the phylum Actinobacteria was strongly linked to the WG pasture bacterial community (Figure 5C). In contrast, the most dominant bacterial genera found in this study were mostly associated with WG pastures (Figure 5D).

(A)

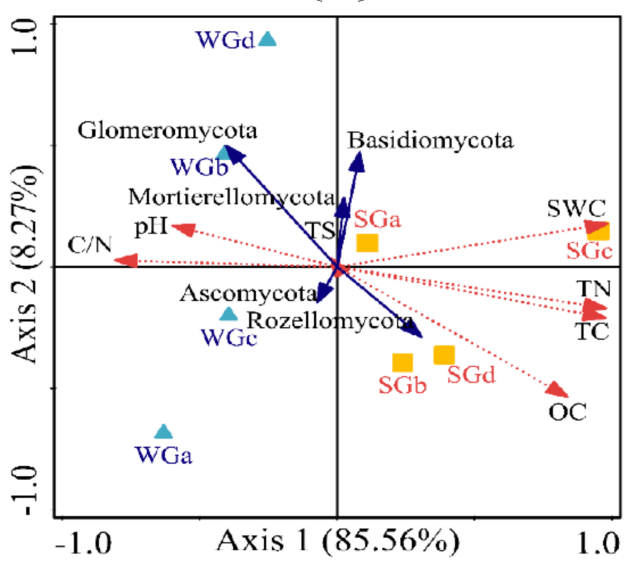

(C)

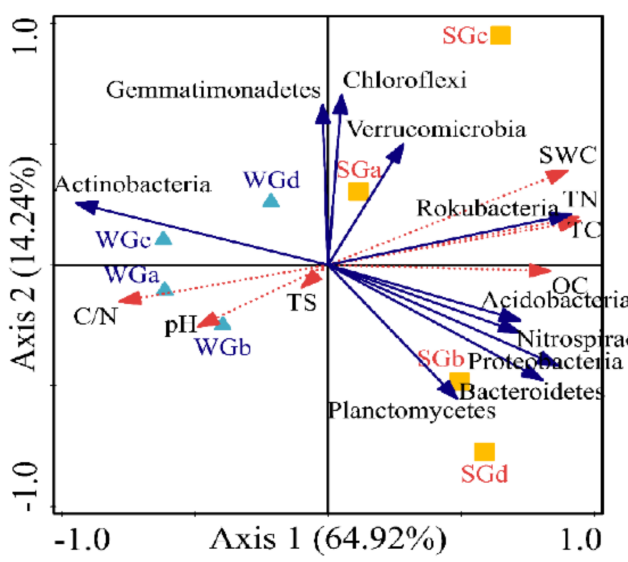

(B)

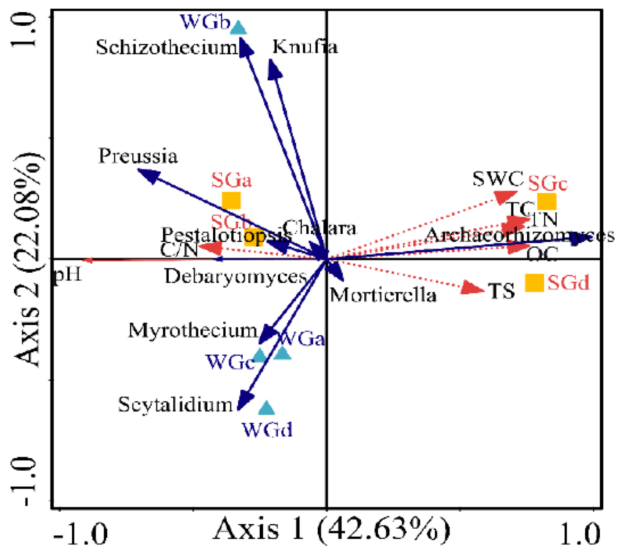

(D)

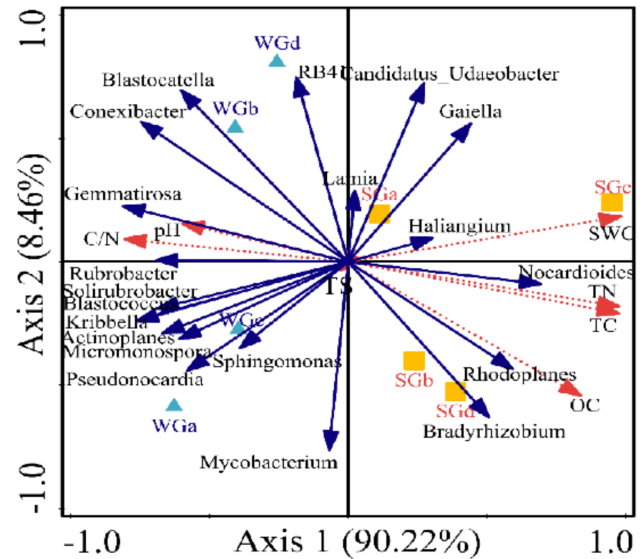

Figure 5. Redundancy analysis (RDA) demonstrating the relationships between dominant fungal phyla (A), fungal genera (B), bacterial phyla (C), and bacterial genera (D) and soil properties. The two axes (Axis 1 and 2) explain the microbial community and soil properties variation between SG and WG pastures. Solid blue and dashed red vectors indicate the microbial taxa and soil parameters, respectively. Yellow squares and blue triangles represent the SG and WG pastures, respectively.

Many studies indicate that Archaeorhizomyces is a widespread fungal genus that appears in many soil habitats, dominant in the rhizosphere [57] and Arctic soils [58]. Their significant, strong, positive relationships with SWC, TC, TN, and OC (Figure 5C) can be attributed to their higher abundances in SG compared to WG pastures, as evidenced in a 
study by Pinto-Figueroa et al. [59]. This result indicates that Archaeorhizomyces are highly sensitive to edaphic factors. The fungal phylum Rozellomycota was only present in SG pastures, perhaps reflecting its potential sensitivity to seasonal variability as indicated by Tedersoo et al. [60].

In the SG pastures, bacterial phyla Verrucomicrobia and Planctomycetes showed opposite relationships to soil properties. Whereas Verrucomicrobia was significantly and positively correlated with $\mathrm{TN}, \mathrm{TC}$, and SWC with a strong negative correlation to soil $\mathrm{pH}$, Planctomycetes responded negatively to TN, TC, and SWC and positively to soil $\mathrm{pH}$ (Table 3). These relationships were different in WG pastures. Apart from this, several other bacterial and fungal phyla also showed significant and strong correlations with soil physicochemical properties (Tables 3 and 4) differently between the SG and WG pastures. This also reflects the importance of seasonal grazing to alter soil properties, affecting microbial community responses. Dominant fungal phyla in our study also showed different strong correlations with different soil chemical properties between SG and WG grazed pastures. Similar observations were reported in Siles et al.'s study [61]. They reported seasonal patterns of soil chemical composition as being linked to soil fungal communities in alpine forest soils.

Table 3. Pearson correlation coefficients (r) between bacterial and fungal phyla and soil properties in summer grazed (SG) pastures. Strong correlations $(\mathrm{r}>0.7$ or $\mathrm{r}<-0.7)$ are indicated in bold $\left({ }^{*} p<0.05 ; * *<0.01\right)$.

\begin{tabular}{|c|c|c|c|c|c|c|c|c|}
\hline Classification & Taxonomy & TN & TC & TS & $\mathrm{pH}$ & OC & $\mathbf{C} / \mathbf{N}$ & SWC \\
\hline \multirow{5}{*}{ Fungi } & Ascomycota & 0.04 & 0.039 & -0.519 & 0.094 & -0.441 & -0.01 & 0.381 \\
\hline & Basidiomycota & 0.126 & 0.112 & 0.728 & -0.387 & 0.519 & -0.342 & -0.19 \\
\hline & Mortierellomycota & -0.135 & -0.091 & -0.252 & 0.522 & 0.149 & 0.772 & -0.284 \\
\hline & Glomeromycota & -0.136 & -0.165 & -0.314 & -0.073 & -0.561 & -0.341 & 0.169 \\
\hline & Rozellomycota & 0.05 & 0.027 & 0.693 & -0.397 & 0.396 & -0.421 & -0.228 \\
\hline \multirow{10}{*}{ Bacteria } & Actinobacteria & -0.097 & -0.098 & -0.619 & 0.211 & -0.558 & 0.08 & 0.252 \\
\hline & Proteobacteria & 0.209 & 0.206 & 0.722 & -0.346 & 0.637 & -0.218 & -0.136 \\
\hline & Acidobacteria & -0.37 & -0.372 & 0.256 & 0.166 & 0.109 & 0.18 & -0.663 \\
\hline & Chloroflexi & -0.136 & -0.147 & -0.553 & 0.136 & -0.603 & -0.055 & 0.215 \\
\hline & Gemmatimonadetes & 0.223 & 0.241 & -0.465 & 0.113 & -0.184 & 0.158 & 0.498 \\
\hline & Verrucomicrobia & $0.938 *$ & $0.941 *$ & 0.488 & -0.723 & 0.67 & -0.555 & $0.990 * *$ \\
\hline & Planctomycetes & -0.675 & -0.643 & -0.532 & 0.843 & -0.337 & 0.918 * & -0.79 \\
\hline & Bacteroidetes & 0.174 & 0.201 & 0.388 & 0.003 & 0.605 & 0.267 & -0.143 \\
\hline & Rokubacteria & 0.69 & 0.716 & 0.068 & -0.268 & 0.452 & -0.042 & 0.778 \\
\hline & Nitrospirae & -0.448 & -0.406 & -0.536 & 0.78 & -0.192 & $0.940 *$ & -0.531 \\
\hline
\end{tabular}

Table 4. Pearson correlation coefficients ( $\mathrm{r}$ ) to illustrate relationships between bacterial and fungal phyla communities and soil properties in winter grazed (WG) pastures. Strong correlations $(\mathrm{r}>0.7$ or $\mathrm{r}<-0.7)$ are indicated in bold $\left({ }^{*} p<0.05 ;{ }^{* *} p<0.01\right)$.

\begin{tabular}{|c|c|c|c|c|c|c|c|c|}
\hline Classification & Taxonomy & TN & TC & TS & $\mathrm{pH}$ & OC & $\mathrm{C} / \mathrm{N}$ & SWC \\
\hline \multirow{4}{*}{ Fungi } & Ascomycota & -0.866 & -0.724 & 0.776 & -0.726 & 0.375 & 0.913 & -0.779 \\
\hline & Basidiomycota & 0.701 & 0.599 & -0.573 & 0.498 & -0.539 & -0.744 & 0.849 \\
\hline & Mortierellomycota & 0.092 & -0.006 & 0.075 & 0.098 & -0.879 & -0.165 & 0.867 \\
\hline & Glomeromycota & 0.103 & -0.201 & -0.128 & 0.787 & -0.315 & -0.237 & 0.354 \\
\hline \multirow{10}{*}{ Bacteria } & Actinobacteria & 0.223 & 0.291 & -0.381 & 0.141 & 0.888 & -0.151 & -0.721 \\
\hline & Proteobacteria & -0.394 & -0.666 & 0.396 & 0.4 & -0.532 & 0.249 & 0.312 \\
\hline & Acidobacteria & 0.024 & -0.002 & 0.14 & -0.104 & -0.78 & -0.066 & 0.74 \\
\hline & Chloroflexi & -0.399 & -0.144 & 0.45844 & -0.881 & 0.003 & 0.491 & -0.207 \\
\hline & Gemmatimonadetes & -0.665 & -0.479 & 0.543 & -0.679 & 0.648 & 0.748 & -0.936 * \\
\hline & Verrucomicrobia & 0.351 & 0.101 & -0.221 & 0.639 & -0.872 & -0.48 & $0.994 * *$ \\
\hline & Planctomycetes & -0.678 & -0.879 & 0.687 & 0.066 & -0.532 & 0.554 & 0.171 \\
\hline & Bacteroidetes & -0.651 & -0.846 & 0.625 & 0.105 & -0.362 & 0.537 & 0.025 \\
\hline & Rokubacteria & 0.211 & 0.391 & -0.104 & -0.41 & -0.153 & -0.137 & 0.24 \\
\hline & Nitrospirae & -0.242 & -0.343 & 0.398 & -0.075 & $-0.931 *$ & 0.155 & 0.753 \\
\hline
\end{tabular}


As found in several previous studies [43,62,63], the differences in bacterial community structure in our study were most likely driven by soil properties. In contrast, the fungal community structure was not perturbed by these factors. Fungi are generally considered to have a competitive advantage over bacteria under low organic conditions $[64,65]$. In this study, SG and WG pastures differed in plant community composition, which may be one of the factors that contributed to differences in soil properties, and thereby microbial composition, between these two pastures. Altitude may impact soil microorganisms [66,67], but those impacts were likely through altering of soil properties via vegetation changes.

Other studies have identified that animal grazing affects soil productivity by regulating the soil microbial community and nutrient turnover [23], and can disturb the microbial diversity associations with biogeochemical processes [68], consequently altering grassland productivity [69]. Our results indicate that microbial responses to grazing can be further complicated by seasonal impacts.

\section{Conclusions}

This study showed that distinct microbial community structures were developed in two pastures, located within reasonable proximity to each other but at different altitudes, grazed by Gansu red deer in two different seasons. Microbial diversity and composition are widely recognized as key factors in driving ecological functions, and this study provides evidence that seasonal rotational grazing can impact these key ecosystem drivers. These results will contribute to understanding soil microbial responses to seasonal grazing.

Author Contributions: Conceptualization, S.B.; investigation, A.N.T., B.K., T.Z., F.H. and S.B.; soil analysis, B.K. and T.Z.; data analysis, A.N.T.; data curation, B.K. and T.Z.; provision of resources, F.H.; writing original draft, A.N.T.; supervision, review and editing, S.B. All authors have read and agreed to the published version of the manuscript.

Funding: This work was supported by the Project of the Second Tibetan Plateau Scientific Expedition (2019QZKK0302), Program for Innovative Research Team of Chinese Ministry of Education (IRT17R50), Strategic Priority Research Program of Chinese Academy of Sciences (XDA2010010203).

Institutional Review Board Statement: Not applicable.

Informed Consent Statement: Not applicable.

Data Availability Statement: The nucleotide sequences retrieved from this study are openly available in the NCBI GenBank. See Section 2.6 for details.

Acknowledgments: Authors are grateful to Shenghua Chang, Zechen Peng, and Zhaofeng Wang for their support during the scientific expedition.

Conflicts of Interest: The authors declare that they have no known competing financial interest or personal relationships that could have appeared to influence the work reported in this paper.

\section{References}

1. Franzluebbers, A.J.; Paine, L.K.; Winsten, J.R.; Krome, M.; Sanderson, M.A.; Ogles, K. Well-Managed Grazing Systems: A Forgotten Hero of Conservation. J. Soil Water Conserv. 2012, 67, 100A-104A. [CrossRef]

2. Powell, J.; Gourley, C.; Rotz, C.A.; Weaver, D.M. Nitrogen Use Efficiency: A Potential Performance Indicator and Policy Tool for Dairy Farms. J. Environ. Sci. 2010, 13, 217-228. [CrossRef]

3. Enri, S.R.; Probo, M.; Farruggia, A.; Lanore, L.; Blanchetete, A.; Dumont, B. A Biodiversity-Friendly Rotational Grazing System Enhancing Flower-Visiting Insect Assemblages While Maintaining Animal and Grassland Productivity. Agric. Ecosyst. Environ. 2017, 241, 1-10. [CrossRef]

4. García, R.R.; Celaya, R.; García, U. Goat Grazing, Its Interactions with Other Herbivores and Biodiversity Conservation Issues. Small Rumin. Res. 2012, 107, 49-64. [CrossRef]

5. Bilotta, G.; Brazier, R. The Impacts of Grazing Animals on the Quality of Soils, Vegetation, and Surface Waters in Intensively Managed Grasslands. Adv. Agron. 2007, 94, 237-280.

6. Greenwood, K. Grazing Effects on Soil Physical Properties and the Consequences for Pastures: A Review. Aust. J. Exp. Agric. 2001, 41, 1231-1250. [CrossRef]

7. O'Connor, K. Comments on Dr Floate's Paper on Grazing Effect by Large Herbivores. Ecol. Bull. 1981, 33, 707-714. 
8. Miao, F.; Guo, Z.; Xue, R.; Wang, X. Effects of Grazing and Precipitation on Herbage Biomass, Herbage Nutritive Value, and Yak Performance in an Alpine Meadow on the Qingha Tibetan Plateau. PLoS ONE 2015, 10, e0127275. [CrossRef]

9. Soder, K.; Rook, A.; Sanderson, M. Interaction of Plant Species Diversity on Grazing Behavior and Performance of Livestock Grazing Temperate Region Pastures. Crop. Sci. 2007, 47, 416-425. [CrossRef]

10. Kauffman, J.B.; Thorpe, A.S. Livestock Exclusion and Belowground Ecosystem Responses in Riparian Meadows of Eastern Oregon. Ecol. Appl. 2004, 14, 1671-1679. [CrossRef]

11. Kobayashi, T.; Hori, Y. Effects of Trampling and Vegetation Removal on Species Diversity and Micro-Environment under Different Shade Conditions. J. Veg. Sci. 1997, 8, 873-880. [CrossRef]

12. Hou, F.J.; Nan, Z.; Xie, Y.; Li, X.; Lin, H. Integrated Crop-Livestock Production Systems in China. Rangel. J. 2008, 30, 221-231. [CrossRef]

13. Taboada, M.A.; Rubio, G.; Enrique, J. Grazing Impacts on Soil Physical, Chemical, and Ecological Properties in Forage Production Systems. In Soil Management: Building a Stable Base for Agriculture; Hatfield, J.L., Thomas, J.S., Eds.; American Society of Agronomy and Soil Science Society of America: Madison, WI, USA, 2011; pp. 301-320.

14. Porensky, L.M.; Derner, J.D.; Augustine, D.J.; Milchunas, D.G. Plant Community Composition after 75 Yr of Sustained Grazing Intensity Treatments in Shortgrass Steppe. Rangel. Ecol. Manag. 2017, 70, 456-464. [CrossRef]

15. Rahmanian, S.; Hejda, M.; Ejtehadi, H.; Farzam, M.; Memariani, F.; Pyšek, P. Effects of Livestock Grazing on Soil, Plant Functional Diversity, and Ecological Traits Vary between Regions with Different Climates in Northeastern Iran. Ecol. Evol. 2019, 9, 8225-8237. [CrossRef] [PubMed]

16. Ramalho, I.O.; Rezende, C.P.; Pereira, J.M.; Macedo, R.O.; Santos, C.A.; Monteiro, R.C.; Boddey, R.M. Deposition and Decomposition of Litter in Periods of Grazing and Rest of a Tropical Pasture under Rotational Grazing. Cienc. Rural 2019, 49. [CrossRef]

17. Sun, Y.; He, X.Z.; Hou, F.J.; Wang, Z.; Chang, S. Grazing Increases Litter Decomposition Rate but Decreases Nitrogen Release Rate in an Alpine Meadow. Biogeosciences 2018, 15, 4233-4243. [CrossRef]

18. Patra, A.; Abbadie, L.; Clays-Josserand, A.; Degrange, V.; Grayston, S.; Loiseau, P. Effects of Grazing on Microbial Functional Groups Involved in Soil N Dynamics. Ecol. Monogr. 2005, 75, 65-80. [CrossRef]

19. Gou, Y.; Nan, Z.; Hou, F.J. Diversity and Structure of a Bacterial Community in Grassland Soils Disturbed by Sheep Grazing in the Loess Plateau of Northwestern China. Genet. Mol. 2015, 14, 16987-16999. [CrossRef]

20. Qi, S.; Zheng, H.; Lin, Q.; Li, G.; Xi, Z.; Zhao, X. Effects of Livestock Grazing Intensity on Soil Biota in a Semiarid Steppe of Inner Mongolia. Plant Soil 2011, 340, 117-126. [CrossRef]

21. Jangid, K.; Williams, M.A.; Franzluebbers, A.J.; Sanderlin, J.S.; Reeves, J.H.; Jenkins, M.B. Relative Impacts of Land-Use, Management Intensity and Fertilization Upon Soil Microbial Community Structure in Agricultural Systems. Soil Biol. Biochem. 2008, 40, 2843-2853. [CrossRef]

22. Zhou, X.; Wang, J.; Hao, Y.; Wang, Y. Intermediate Grazing Intensities by Sheep Increase Soil Bacterial Diversities in an Inner Mongolian Steppe. Biol. Fertil. Soils 2010, 46, 817-824. [CrossRef]

23. Xun, W.; Yan, R.; Ren, Y.; Jin, D.; Xiong, W.; Zhang, G. Grazing-Induced Microbiome Alterations Drive Soil Organic Carbon Turnover and Productivity in Meadow Steppe. Microbiome 2018, 6, 170. [CrossRef] [PubMed]

24. Qu, T.; Du, W.; Yuan, X.; Yang, Z.; Liu, D.; Wang, D.; Yu, L. Impacts of Grazing Intensity and Plant Community Composition on Soil Bacterial Community Diversity in a Steppe Grassland. PLoS ONE 2016, 11, e0159680. [CrossRef] [PubMed]

25. Zhang, C.; Liu, G.; Song, Z.; Wang, J.; Guo, L. Interactions of Soil Bacteria and Fungi with Plants During Long-Term Grazing Exclusion in Semiarid Grasslands. Soil Biol. Biochem. 2018, 124, 47-58. [CrossRef]

26. Xiao, X.; Li, D.C.; An, Y.F.; Ma, Z.W.; Wu, Z.; Peng, Z.C.; Hou, F.J. Plant community characteristics of grazing grassland in a deer farm in summer. Pratacultural Sci. 2019, 36, 1693-1705.

27. Flora of China. Available online: http:/ / www.efloras.org/florataxon.aspx?flora_id=2\&taxon_id (accessed on 9 February 2021).

28. Ma, Z.W.; Wang, H.; Yu, Y.W.; Chang, S.H.; Zhou, Q.P.; Hou, F.J. Short-term effect of mowing winter pastures of Gansu wapiti on forage regeneration. Pratacultural Sci. 2018, 35, 157-164.

29. Nelson, D.W.; Sommers, L.E. Total Carbon, Organic Carbon, and Organic Matter. In Methods of Soil Analysis: Part 3 Chemical Methods; Sparks, D.L., Page, A.L., Helmke, P.A., Loeppert, R.H., Soltanpour, P.N., Tabatabai, M.A., Johnston, C.T., Sumner, M.E., Eds.; American Society of Agronomy and Soil Science Society of America: Madison, WI, USA, 1996; Volume 5, pp. 961-1010.

30. Kang, B.; Bowatte, S.; Hou, F.J. Soil Microbial Communities and Their Relationships to Soil Properties at Different Depths in an Alpine Meadow and Desert Grassland in the Qilian Mountain Range of China. J. Arid Environ. 2020, 184, 104316. [CrossRef]

31. Chao, A. Nonparametric estimation of the number of classes in a population. Scand. J. Stat. 1984, 11, 265-270. [CrossRef]

32. Shannon, C. A mathematical theory of communication. Bell Syst. Tech. J. 1948, 27, 379-423. [CrossRef]

33. Altschul, S.F.; Madden, T.L.; Schäffer, A.A.; Zhang, J.; Zhang, Z.; Miller, W.; Lipman, D.J. Gapped Blast and Psi-Blast: A New Generation of Protein Database Search Programs. Nucleic Acids Res. 1997, 25, 3389-3402. [CrossRef]

34. R Core Team. A Language and Environment for Statistical Computing [Computer Software Manual]; R Foundation for Statistical Computing: Vienna, Austria, 2013.

35. Liu, J.; Feng, C.; Wang, D.; Wang, L.; Wilsey, B.J.; Zhong, Z.J. Impacts of Grazing by Different Large Herbivores in Grassland Depend on Plant Species Diversity. J. Appl. Ecol. 2015, 52, 1053-1062. [CrossRef] 
36. He, Y.; Xu, M.; Qi, Y.; Dong, Y.; He, X.; Li, J.; Sun, L. Differential Responses of Soil Microbial Community to Four-Decade Long Grazing and Cultivation in a Semi-Arid Grassland. Sustainability 2017, 9, 128. [CrossRef]

37. Metzger, K.; Coughenour, M.; Reich, R.; Boone, R. Effects of Seasonal Grazing on Plant Species Diversity and Vegetation Structure in a Semi-Arid Ecosystem. J. Arid Environ. 2005, 61, 147-160. [CrossRef]

38. Pulungan, M.A.; Suzuki, S.; Gavina, M.K.A.; Tubay, J.M.; Ito, H.; Nii, M.; Shiyomi, M. Grazing Enhances Species Diversity in Grassland Communities. Sci. Rep. 2019, 9, 1-8. [CrossRef]

39. Yuan, H.; Hou, F.J. Grazing Intensity and Soil Depth Effects on Soil Properties in Alpine Meadow Pastures of Qilian Mountain in Northwest China. Acta Agric. Scand. B Soil Plant Sci. 2015, 65, 222-232. [CrossRef]

40. Ingram, L.; Stahl, P.; Schuman, G.; Buyer, J.; Vance, G.; Ganjegunte, G.; Derner, J. Grazing Impacts on Soil Carbon and Microbial Communities in a Mixed-Grass Ecosystem. Soil Sci. Soc. Am. J. 2008, 72, 939-948. [CrossRef]

41. Davis, K.E.; Sangwan, P.; Peter, H.J. Acidobacteria, Rubrobacteridae, and Chloroflexi Are Abundant among Very Slow-Growing and Mini-Colony-Forming Soil Bacteria. Environ. Microbiol. 2011, 13, 798-805. [CrossRef]

42. Deng, J.; Yin, Y.; Zhu, W.; Zhou, Y. Variations in Soil Bacterial Community Diversity and Structures among Different Revegetation Types in the Baishilazi Nature Reserve. Front. Microbiol. 2018, 9, 2874. [CrossRef]

43. Zeng, Q.; Dong, Y.; An, S. Bacterial Community Responses to Soils Along a Latitudinal and Vegetation Gradient on the Loess Plateau, China. PLoS ONE 2016, 11, e0152894. [CrossRef]

44. Belov, A.A.; Cheptsov, V.S.; Vorobyova, E.A. Soil Bacterial Communities of Sahara and Gibson Deserts: Physiological and Taxonomical Characteristics. AIMS Microbiol. 2018, 4, 685. [CrossRef] [PubMed]

45. Mohammadipanah, F.; Wink, J. Actinobacteria from Arid and Desert Habitats: Diversity and Biological Activity. Front. Microbiol. 2016, 6, 1541. [CrossRef]

46. Ma, X.; Chen, B.; Luo, S.; Ma, B.; Qi, W.; Cao, C.; Du, G. Increasing Soil pH Enhances the Network Interactions among Bacterial and Archaeal Microbiota in Alpine Grasslands of the Tibetan Plateau. Prepr. Res. Sq. 2019, PPR149373. [CrossRef]

47. Mohanta, T.K.; Bae, H. The Diversity of Fungal Genome. Biol. Proced. Online 2015, 17, 8. [CrossRef]

48. Wang, H.; Guo, S.; Huang, M.; Thorsten, L.H.; Wei, J. Ascomycota Has a Faster Evolutionary Rate and Higher Spe-cies Diversity Than Basidiomycota. Sci. China Life Sci. 2010, 53, 1163-1169. [CrossRef]

49. Malik, A.A.; Chowdhury, S.; Schlager, V.; Oliver, A.; Puissant, J.; Vazquez, P.G.; Gleixner, G. Soil Fungal: Bacterial Ratios Are Linked to Altered Carbon Cycling. Front. Microbiol. 2016, 7, 1247. [CrossRef]

50. Zhong, Z.; Zhang, X.; Wang, X.; Fu, S.; Wu, S.; Lu, X. Soil Bacteria and Fungi Respond Differently to Plant Diversity and Plant Family Composition During the Secondary Succession of Abandoned Farmland on the Loess Plateau, China. Plant Soil. 2020, 448, 183-200. [CrossRef]

51. Prober, S.M.; Leff, J.W.; Bates, S.T.; Borer, E.T.; Firn, J.; Harpole, W.S.; Bakker, J.D. Plant diversity predicts beta but not alpha diversity of soil microbes across grasslands worldwide. Ecol. Lett. 2015, 18, 85-95. [CrossRef] [PubMed]

52. Maestre, F.T.; Delgado-Baquerizo, M.; Jeffries, T.C.; Eldridge, D.J.; Ochoa, V.; Gozalo, B.; Ulrich, W. Increasing Aridity Reduces Soil Microbial Diversity and Abundance in Global Drylands. Proc. Natl. Acad. Sci. USA 2015, 112, 15684-15689. [CrossRef] [PubMed]

53. Wang, X.; He, T.; Gen, S.; Zhang, X.Q.; Wang, X.; Jiang, D.; Zhang, W. Soil properties and agricultural practices shape microbial communities in flooded and rainfed croplands. Appl. Soil Ecol. 2020, 147, 103449. [CrossRef]

54. O’Brien, F.J.M.; Almaraz, M.; Foster, M.; Hill, A.; Huber, D.; King, E.; Miller, V. Soil Salinity and Ph Drive Soil Bacterial Community Composition and Diversity Along a Lateritic Slope in the Avon River Critical Zone Observatory, Western Australia. Front. Microbiol. 2019, 10, 1486. [CrossRef] [PubMed]

55. Wang, C.; Zhou, X.; Guo, D.; Zhao, J.; Yan, L.; Feng, G.; Zhao, L. Soil pH is the Primary Factor Driving the Distribution and Function of Microorganisms in Farmland Soils in Northeastern China. Ann. Microbiol. 2019, 69, 1461-1473. [CrossRef]

56. Xue, P.P.; Carrillo, Y.; Pino, V.; Minasny, B.; McBratney, A.B. Soil Properties Drive Microbial Community Structure in a Large Scale Transect in South Eastern Australia. Sci. Rep. 2018, 8, 11725. [CrossRef]

57. Urbina, H.; Breed, M.F.; Zhao, W.; Gurrala, K.L.; Andersson, S.G.; Ågren, J.; Rosling, A. Specificity in Arabidopsis Thaliana Recruitment of Root Fungal Communities from Soil and Rhizosphere. Fungal Biol. 2018, 122, 231-240. [CrossRef]

58. Dahl, M.B.; Priemé, A.; Brejnrod, A.; Brusvang, P.; Lund, M.; Nymand, J.; Haugwitz, M.S. Warming, shading and a moth outbreak reduce tundra carbon sink strength dramatically by changing plant cover and soil microbial activity. Sci. Rep. 2017, 7, 1-13. [CrossRef]

59. Pinto-Figueroa, E.A.; Seddon, E.; Yashiro, E.; Buri, A.; Niculita-Hirzel, H.; Van Der Meer, J.R.; Guisan, A. Archaeorhizo-mycetes Spatial Distribution in Soils Along Wide Elevational and Environmental Gradients Reveal Co-Abundance Patterns with Other Fungal Saprobes and Potential Weathering Capacities. Front. Microbiol. 2019, 10, 656. [CrossRef] [PubMed]

60. Tedersoo, L.; Bahram, M.; Puusepp, R.; Nilsson, R.H.; James, T.Y. Novel Soil-Inhabiting Clades Fill Gaps in the Fungal Tree of Life. Microbiome 2017, 5, 42. [CrossRef]

61. Siles, J.A.; Cajthaml, T.; Filipova, A.; Minerbi, S.; Margesin, R. Altitudinal, Seasonal and Interannual Shifts in Mi-crobial Communities and Chemical Composition of Soil Organic Matter in Alpine Forest Soils. Soil Biol. Biochem. 2017, 112, 1-13. [CrossRef]

62. Barnett, S.E.; Youngblut, N.D.; Buckley, D.H. Soil Characteristics and Land-Use Drive Bacterial Community Assembly Patterns. FEMS Microbiol. Ecol. 2020, 96, fiz194. [CrossRef] [PubMed] 
63. Kaiser, K.; Wemheuer, B.; Korolkow, V.; Wemheuer, F.; Nacke, H.; Schöning, I.; Daniel, R. Driving Forces of Soil Bacterial Community Structure, Diversity, and Function in Temperate Grasslands and Forests. Sci. Rep. 2016, 6, 1-12. [CrossRef] [PubMed]

64. Gómez-Brandón, M.; Probst, M.; Siles, J.A.; Peintner, U.; Bardelli, T.; Egli, M.; Ascher-Jenull, J. Fungal Communities and Their Association with Nitrogen-Fixing Bacteria Affect Early Decom-position of Norway Spruce Deadwood. Sci. Rep. 2020, 10, 1-11.

65. Koranda, M.; Kaiser, C.; Fuchslueger, L.; Kitzler, B.; Sessitsch, A.; Zechmeister-Boltenstern, S.; Richter, A. Fungal and Bacterial Utilization of Organic Substrates Depends on Substrate Complexity and N Availability. FEMS Microbiol. Ecol. 2014, 87, 142-152. [CrossRef] [PubMed]

66. Kumar, S.; Suyal, D.C.; Yadav, A.; Shouche, Y.; Goel, R. Microbial Diversity and Soil Physicochemical Characteristic of Higher Altitude. PLoS ONE 2019, 14, e0213844. [CrossRef]

67. Siles, J.A.; Cajthaml, T.; Minerbi, S.; Margesin, R. Effect of Altitude and Season on Microbial Ac-tivity, Abundance and Community Structure in Alpine Forest Soils. FEMS Microbiol. Ecol. 2016, 92, fiw008. [CrossRef]

68. Wang, Y.; Wang, J.; Chen, C.; Li, J.; Chu, J. Grazing Plays an Important Role in Structuring Alpha and Beta Compo-nents of Taxonomic, Functional, and Phylogenetic Diversity in Semiarid Sandy Land of Northern China. Glob. Ecol. Conserv. 2019, 20, e00790. [CrossRef]

69. Cao, Y.; Wu, J.; Zhang, X.; Niu, B.; Li, M.; Zhang, Y.; Wang, Z. Dynamic Forage-Livestock Balance Analysis in Alpine Grasslands on the Northern Tibetan Plateau. J. Environ. Manag. 2019, 238, 352-359. [CrossRef] [PubMed] 